\title{
Izrael i jego „misterium" w komentarzach do Listu do Rzymian św. Tomasza z Akwinu i Marcina Lutra
}

\author{
ks. Łukasz Kamykowski \\ Uniwersytet Papieski Jana Pawła II w Krakowie \\ lukasz.kamykowski@upjp2.eu.pl (D) https://orcid.org/0000-0001-9669-0939
}

W starożytności chrześcijańskiej już od II wieku zaczyna się kształtować takie rozumienie roli Starego Testamentu dla życia Kościoła i jego teologii, w którym Żydzi nieprzyjmujący Jezusa nie mają już pozytywnego znaczenia dla dalszych dziejów zbawienia, Kościół przejął bowiem wszystkie prerogatywy dawnego ludu Izraela. Można mnożyć przykłady przewijania się przez teologię i kaznodziejstwo patrystyczne i średniowieczne owej idei zastępstwa i związanej z nią deprecjacji Żydów i Synagogi. Trudno śledzić powolne zmiany dokonujące się w tym względzie ${ }^{1}$. Posiadamy jednak (także w polskim przekładzie) dwa w pełni opracowane komentarze do Listu do Rzymian autorów o kolosalnym znaczeniu dla dziejów myśli europejskiej - Tomasza z Akwinu i Marcina Lutra. Warto przyjrzeć się, jak potraktowany został Izrael i jego „misterium” w ich komentarzach, zwracając uwagę zwłaszcza na 11 rozdział Listu.

\section{Tomasza z Akwinu Wykład Listu do Rzymian}

Św. Tomasz z Akwinu (1224/1225-1274)² jest autorem, który w naszej pracy reprezentuje myśl egzegetyczną dojrzałego średniowiecza.

1 Trudność dotyczy także braku opracowań krytycznych i tekstów dostępnych w języku polskim, które by mogły służyć przykładem dla dokonujących się zmian.

2 Por. J. A. Weisheipl, Tomasz z Akwinu. Życie, myśl i dzieło, W drodze, Poznań 1985. 
Syn Teodory i Landulfa ze znacznego rodu rycerskiego został przeznaczony przez rodziców do stanu duchownego. Pobiera więc staranną naukę, najpierw u benedyktynów na Monte Cassino, potem w utworzonym przez cesarza Fryderyka II uniwersytecie w Neapolu. W roku 1244 wstępuje do niedawno powstałego zakonu dominikanów. Mimo zdecydowanego sprzeciwu rodziny ostatecznie stawia na swoim. W roku 1245 zostaje przez władze zakonne wysłany do Paryża na dalsze studia. Przez parę lat studiuje w Kolonii pod kierunkiem św. Alberta, potem wraca do Paryża. Całe życie poświęca studiom filozoficzno-teologicznym w okresie dojrzewania średniowiecznego systemu uniwersyteckiego. W latach 1265-1268 podczas burzliwych lat walki cesarstwa z papiestwem tworzy dominikański ośrodek studiów w Neapolu, w tym czasie przebywa też w Rzymie i Viterbo. Zaczyna wówczas pisać Summę teologiczna, mającą stanowić główne dzieło, dzięki któremu wpisuje się trwale w historię filozofii i teologii, oddziałując na całą późniejszą myśl Zachodu. 6 XII 1273 przeżycie mistyczne w trakcie mszy świętej zmienia jego nastawienie do całego dorobku życia. Jest wtedy w drodze na Sobór w Lyonie i w czasie drogi umiera.

Wykłady na temat Listów Pawłowych prowadził Tomasz w Italii po raz pierwszy w latach 1259-1265 (Anagni, Orvieto) i z tej serii zachowała się reportatio (czyli autoryzowane notatki z wykładów mistrza) opracowana przez Reginalda z Piperino. Po raz drugi święty zaczął wykładać Listy pod koniec życia w Neapolu (1272-1273). Biografowie Tomasza twierdzą, że opracowywał je już wcześniej w Paryżu; w pewnym miejscu natrafił na poważną trudność i przerwał pracę nad wykładem, aż doznał oświecającego olśnienia podczas modlitwy. Tę drugą serię wykładów doprowadził do połowy 1 Listu do Koryntian; w całości wyłożył więc tylko List do Rzymian.

Znana dziś redakcja stanowiąca podstawę przekładu Jacka Salija OP jest dopracowaną przez samego Tomasza expositio, która zawiera dyskusje z wcześniejszymi komentatorami oraz kojarzące się autorowi odnośniki do innych miejsc Pisma Świętego i innych autorytetów filozofii i teologii średniowiecznej (Augustyn, Arystoteles...). Metoda komentowania polega na traktowaniu Pisma Świętego jako całości, 
w której jednak trzeba dostrzec i rozważyć naturalne części logiczne aż po poszczególne zdania i kluczowe wyrazy, przeanalizować je i na tej podstawie dać obraz całego komentowanego tekstu. Idee wiodące Tomaszowego komentowania wiążą się ze sporem augustyńsko-pelagiańskim na temat wolności, łaski, zbawienia. Temat relacji Izraela i Kościoła jest traktowany w zależności od tych zagadnień. Wykład wstępny poświęca autor w całości osobie św. Pawła i okolicznościom powstania jego pism, potem przechodzi (wykład 1) do rozważań na temat misji głosiciela ewangelii. Przedmiotem naszej analizy będą wykłady od drugiego do piątego na 11 rozdział Listu św. Pawła do Rzymian.

\section{Marcina Lutra Komentarz do Listu do Rzymian ${ }^{3}$}

Marcin Luter (1483-1546) urodził się w Saksonii (Mansfeld) w rodzinie związanej z kopalniami miedzi. Jego ojciec Hans - przedsiębiorca w tej branży - dbał o wykształcenie gromadki dzieci (w roku 1505 Marcin miał żyjących 4 braci i 4 siostry). Pobożność domu była typowa dla regionu i czasu: chrześcijańska z domieszką zabobonów pogańskich. Przejawiało się to między innymi w żywej radości z okazji świąt roku kościelnego i lęku przed karami czyśćcowymi i piekielnymi.

Marcin uczęszcza z sukcesem do kolejnych szkół (Mansfeld, Magdeburg, Eisenach), a w 1501 roku zaczyna studia uniwersyteckie w Erfurcie i kończy (trivium i quadrivium) w styczniu 1505 roku. Latem tego roku przeżywa kryzys psychiczny i duchowy, w którym ważnym elementem jest trwoga przed surowym Bogiem, który z pewnością go potępia. Punktem zwrotnym tego kryzysu jest burza, która zaskakuje go w drodze, bardzo bliskie uderzenie pioruna i złożona w tym momencie obietnica wstąpienia do klasztoru, jeśli ocaleje. Waha się i radzi, czy to zobowiązanie było wiążące; ostatecznie rozpoczyna

3 Por. M. Luter, Komentarz do Listu do Rzymian, Tymbes, Goleszów 2009; J. M. Todd, Marcin Luter, przekł. T. Szafrański, posł. A. Skowronek, Vocatio, Warszawa 1998; R. Friedenthal, Marcin Luter, Państwowy Instytut Wydawniczy, Warszawa 1991; O. H. Pesch, Zrozumieć Lutra, przeł. A. Marniok i K. Kowalik, W drodze, Poznań 2008. 
nowicjat u zreformowanych augustianów (jesienią 1505 roku). Jako augustianin - zdolny i gorliwy - przeżywa coraz większą trwogę przed nieskończonym Bogiem i Chrystusem-Sędzią, których nie jest w stanie przejednać jakąkolwiek pokutą. Równolegle kończy dalsze studia. Wykłada w Erfurcie już od roku 1509. Skierowany przez zakon na nowy Uniwersytet w Wittemberdze komentuje Sentencje Piotra Lombarda i (w zastępstwie profesora) - Pismo Święte. Zaczyna wtedy odkrywać własne rozumienie Listów św. Pawła, zwłaszcza do Galatów i do Rzymian, i wypracowywać własny traktat dogmatyczny: mocno oparty o Biblię i nastawiony duszpastersko. Bulwersuje go w tym czasie zabobonne traktowanie odpustów i zdobywanie ich za cenę datków wpłacanych na budowę nowej bazyliki św. Piotra w Rzymie. W Wittemberdze kwestują dominikanie, z którymi zakon augustiański jest skonfliktowany. To, co miało stać się początkiem reformacji: wezwanie do publicznej debaty w oparciu o 95 tez na temat praktyki odpustów, wciągnęło żarliwego, przenikliwego intelektualnie, ambitnego i porywczego jednocześnie doktora Lutra w wir zdarzeń, w których powszechne wówczas pragnienie reformy Kościoła zostało sprzężone z polityką... Zamiast dysputy teologicznej przychodzi wezwanie do odwołania wyrwanych z kontekstu tez z groźbą sankcji kanonicznych... W tym klimacie powstaje interesujący nas komentarz.

Po doktoracie z teologii (1513) i powierzeniu mu kazań w kościele farnym w Wittenberdze Luter komentuje Biblię, zaczynając od Księgi Psalmów. Przygotowując wykład do psalmów 70 (69) i 71 (70) formułuje swe rozwiązanie problemu gniewu Boga, grzeszności człowieka i miłosierdzia podarowanego przez Ojca w Chrystusie ukrzyżowanym i opuszczonym. Komentując psalmy, opiera się na Augustynowych Enarrationes in Psalmos i Wyznaniach. Komentarz do Listu do Rzymian powstaje po wykładach komentujących Psalmy (1513-1515) od jesieni 1515 do jesieni 1516 roku. Następnie aż do początku konfliktu z Rzymem komentuje List do Galatów i List do Hebrajczyków (do 1517/1518).

Komentarz ma mocny rys chrystocentryczny, w centrum zainteresowania komentatora jest wiara jako postawa przylgnięcia do Chrystusa, które jest narzędziem czerpania łaskawości Boga. Rozpoczynając swoje wykłady do pierwszego rozdziału, pisze: 
Celem listu apostolskiego jest zniweczyć wszelką mądrość i uczynki ciała, bez względu na to, jak ważne wydają się w naszych oczach i w oczach innych i bez względu na to, jak szczerymi i gorliwymi możemy być w ich praktykowaniu. W miejsce tego wszczepia, pogłębia i potęguje poczucie grzechu, niezależnie od tego, czy jest go dużo, czy mało ${ }^{4}$.

Problematyka misterium Izraela pozostaje w cieniu głównych idei komentarza. Treść interesującego nas 11 rozdziału Marcin Luter charakteryzuje następująco:

Apostoł karci pogan za urąganie Żydom, pokazuje teraźniejsze zaślepienie Żydów i głębię Bożej mądrości. Poganie nie powinni gardzić Żydami, lecz pamiętać, że są zbawieni $\mathrm{z}$ łaski, jak wybrani w Izraelu ${ }^{5}$.

W ciągu całego rozwoju myśli chrześcijańskiej na odczytanie Listu św. Pawła do Rzymian ogromny wpływ ma poruszana we wcześniejszych partiach tekstu sprawa, dla samego Apostoła chyba raczej pomocnicza, odpowiedzialności całej ludzkości - zarówno pogan, jak i Żydów - za odejście od Bożych planów. Zostaje ona przeniesiona na teren dyskusji o stosunku wolności i łaski, często w oderwaniu od głównej troski św. Pawła o los jednych i drugich oraz ich wzajemnych odniesień w Bożym zamyśle zbawienia świata przez Jezusa Chrystusa. Zobaczmy jednak bardziej szczegółowo, jak w związku z tym mistrzowie Tomasz i Marcin rozumieją misterium zbawienia Izraela ogłoszone przez Apostoła w 11 rozdziale Listu. Komentatorzy już od Orygenesa zwracają uwagę przede wszystkim na moralne wnioski ważne dla ich adresatów dystansujących się od Żydów, stąd fragment ten traktują krótko. Podobnie i ci dwaj. Zobaczmy jednak dokładniej, co piszą na ten temat.

4 M. Luter, Komentarz do Listu do Rzymian, dz. cyt., s. 22.

5 Tamże, s. 165. 


\section{Misterium, co do którego nie można trwać w niewiedzy}

Tomasz z Akwinu zauważa pożytek poznania tajemnicy zbawienia całego Izraela dla wszystkich wiernych (nie tylko dla „doskonałych”). Przestrzega ich jednak przed pychą, pogardą dla innych ${ }^{6}$. Tomasz wyraźnie zaznacza zasadę usprawiedliwienia z łaski przez wiarę w Chrystusa jako podstawę pokory wobec innych - tu: Żydów odrzucających Ewangelię. Akcentuje wnioski moralne ${ }^{7}$. Przedstawiając tezę Pawła, zauważa, że chodzi nie o zbawienie (dzięki nawróceniu) niektórych (jak to się dzieje w jego czasach), lecz o Izraela jako całość „wówczas” czyli po wejściu „pełni pogan”8. „Dowód” Pawłowy zostaje rozbity na część biblijną i rozumową - do cytowanych przez Pawła fragmentów Biblii Tomasz dodaje własne. Wydobywa charakter zbawienia zaoferowanego Izraelowi: dzięki krwi Chrystusa przez zgładzenie win, co „wówczas” będzie „łatwe” dla Boga ${ }^{9}$. Fragment Listu do Rzymian, który nas najbardziej interesuje, Marcin Luter traktuje bardzo krótko. Warto wszakże zauważyć tytuł, który nadaje tej partii wykładu: „Wybrani z Izraela będą zbawieni przez łaskę"10 (a nie ze względu na uczynki Prawa). Luter uważa cały fragment za nieprzystępny i komentuje go w oparciu o autorytet Ojców ${ }^{\mathbf{1 1}}$ jako zapowiedź powrotu Izraela „do wiary" u kresu czasu:

Z tego fragmentu zazwyczaj wyciąga się wniosek, że przy końcu świata Żydzi zostaną przywróceni do wiary. [...] Znaczenie zatem jest następujące: Żydzi, którzy teraz upadli, zostaną nawróceni i zbawieni, po tym jak poganie dopełnią liczbę wybranych. Nie pozostaną odrzuconymi na zawsze, lecz we właściwym dla nich czasie zostaną nawróceni ${ }^{12}$.

6 Tomasz z Akwinu, Wykład Listu do Rzymian. Super epistolam S. Pauli Apostoli ad Romanos, w tł. i oprac. J. Salija, Wydawnictwo Polskiej Prowincji Dominikanów W drodze, Poznań 1987, s. 178.

7 Tamże, s. 177.

8 Tamże, s. 178-179.

9 Tamże, s. 179.

10 M. Luter, Komentarz do Listu do Rzymian, dz. cyt., s. 173.

11 „Fragment ten jest tak nieprzystępny, że raczej nikt nie uzyska w pełni jasnego zrozumienia, jeśli nie podąży za myślą Ojców, którzy tak właśnie apostoła odczytują” (tamże).

12 Tamże. 
Nawet jeśli obu komentatorów nie interesuje sam w sobie plan Boży wobec Izraela, to przy ich nastawieniu na praktyczne wnioski ważne dla pobożności chrześcijańskiej słuchaczy ich wykładów nie mogą nie zauważyć rozważań świętego Pawła o wzajemnym powiązaniu posłuszeństwa i nieposłuszeństwa z miłosierdziem Bożym, które autor epistoły przedstawia na przykładzie Żydów i pogan. Znajdziemy więc sporo uwag do Rz 11, 11-24 i 28-29. Mimo różnic w ocenie Żydów nieprzyjmujących Ewangelii obaj komentatorzy myślą o aktualizacji tekstu dla swoich adresatów, nie uważając troski św. Pawła o jego rodaków za własną. Oni sami i ich Kościoły to zagrożeni grzechem pychy uczniowie Chrystusa wywodzący się z innych ludów i narodów.

Podstawę do odpowiedzi na pytanie o „potknięcie” Żydów św. Tomasz z Akwinu dostrzega w ogólnej zasadzie dopuszczania przez Boga zła tylko dla wyprowadzenia stąd większego dobra. Rozumowanie Apostoła w odpowiedzi na postawione przezeń pytanie: „Czy aż tak się potknęli, że całkiem upadli?” widzi właśnie jako zastosowanie tej zasady. Wcześniej jednak rozważa dwa możliwe sposoby interpretacji samego pytania:

Można to rozumieć dwojako. Najpierw tak: Czyżby Bóg po to tylko pozwolił im się potknąć, żeby upadli? Inaczej mówiąc: Czyż nie wynika stąd żadna inna korzyść, lecz chciał tylko tego, żeby upadli?

Tomasz w imieniu autora tekstu natchnionego kategorycznie zaprzecza:

Byłoby to przecież niezgodne z Bożą dobrocią, która - jak powiada Augustyn w Podręczniku ${ }^{13}$ - jest tak wielka, że Bóg nigdy nie pozwoliłby na to, żeby stało się jakieś zło, chyba że ze względu na dobro, jakie z tego zła wydobywa. Stąd czytamy w Hi 34, 24: „Rozbija licznych i niezliczonych, a innych w ich miejsce osadza”. Oraz w Ap 3, 11: „Strzeż tego, co posiadasz, aby kto inny nie odebrał ci wieńca”. Bóg bowiem w taki sposób dopuszcza do upadku niektórych, że dla innych upadek ten jest sposobnością do zbawienia.

13 Enchiridion ad Laurentium. Por. św. Augustyn, Podręcznik dla Wawrzyńca, [w:] tenże, Pisma katechetyczne, Warszawa 1952, s. 84. 
Św. Tomasz jednak skłania się ku innej możliwej interpretacji wersetu Rz 11, 11.

Można to rozumieć jeszcze inaczej: „Czy aż tak się potknęli, że upadli?” Innymi słowy: Czy mają trwać w tym upadku na zawsze? „Czyż temu, kto śpi, już nie będzie dane powstać?” (Ps 40, 9) ${ }^{14}$.

W dalszym ciągu wykładu widać wciąż próbę rozważenia wszystkich logicznie możliwych odpowiedzi na postawione przez Apostoła pytanie oraz dyskusję z wcześniejszymi komentarzami, do której Tomasz dołącza kojarzące mu się z tym odnośniki do innych miejsc Pisma oraz innych autorytetów ${ }^{15}$.

Marcin Luter zna opieranie się Żydów w swej ufności na wierności Boga wobec obietnicy, ale uważa ją za niesłuszną, gdy chcą tym „wesprzeć swą dumę”. Akcentuje argument Pawła z własnej niegodności, by podkreślić boską wolę zbawienia grzeszników, których On do tego przeznaczył. Pisze:

[Apostoł] podsumowuje to, co rozpoczął w rozdziale dziewiątym, gdy powiedział „Lecz nie można, żeby miało upaść słowo Boże” $(\mathrm{Rz} 9,6)^{16}$. [...] Zajmuje się tym tematem z wielką powagą, zależy mu bowiem na starciu w proch zuchwałego chlubienia się Żydów w kwestii zasług, a to poprzez podkreślanie pewnej i niezmiennej wierności Boga. Żydzi mogliby odpowiedzieć: Bóg nie odrzuci swego ludu, ponieważ dał mu swą obietnicę ${ }^{17}$.

I kontynuując domniemaną odpowiedź Żydów na zastanawianie się Pawła, czy Bóg nie odrzucił swego ludu, skoro przyjął do łaski pogan, ciągnie dalej:

14 Św. Tomasz z Akwinu, Wykład Listu do Rzymian, dz. cyt., s. 173.

15 Tamże, s. 173-176.

16 Polski przekład komentarza Marcina Lutra, z którego korzystamy, cytuje Pismo Święte według Biblii Gdańskiej - przekładu powszechnie stosowanego wśród polskich protestantów.

17 M. I. Luter, Komentarz do Listu do Rzymian, dz. cyt., s. 166-167. 
A jeśli to, co mówisz, jest prawdą, wówczas Bóg prawdziwie odrzucił swój lud. Tak oto w odwoływaniu się do Bożej wierności upatrywali wsparcia dla własnej dumy; i czynią tak aż po dziś dzieńn ${ }^{18}$.

Dalej następuje gwałtowny atak autora komentarza na „urojoną pobożność” pysznych (Żydów i heretyków), czczących Boga „według własnego przekonania”. Skoro Bóg w cytowanej przez Pawła odpowiedzi danej uskarżającemu się Eliaszowi odpowiada, że zachował sobie cząstkę Izraela, która nie zgięła kolan przed Baalem, Luter próbuje ją zaktualizować i znaleźć praktyczny sens tej odpowiedzi.

„Baal był to bożek. [...] Izraelici wielbili prawdziwego Boga pod postacią bałwochwalczych ceremonii i imion. Lecz właśnie tego Bóg zabronił. Nie mieli czynić sobie żadnych rytych obrazów, czyli podobizn czegokolwiek (por. Wj 20,4)”. Tymczasem usprawiedliwiając się, że czczą w podobiznach prawdziwego Boga i sprzeciwiając się prorokom, którzy ich z tego powodu napominali, stali się pyszni. „Baal to złowieszczy przykład bałwochwalczej sprawiedliwości i pobożności, która jak świat długi i szeroki panoszy się po dziś dzień. Tak oto Żydzi i heretycy czczą Boga według własnego przekonania, a w swoim bałwochwalczym zapale i dziwacznej pobożności są gorsi niż bezbożnicy. Ze względu na Boga stają się nieprzyjaciółmi Boga, ze strachu przed Bogiem zaczynają Nim gardzić. Z powodu pobożności zaczynają zakłócać pokój; przez swoją miłość i świętość stają się zawistni i przewrotni; w interesie pokory stają się butni. Taka właśnie jest urojona pobożność opornych umysłów i obłudnego rozumowania, i to z zaciętym uporem. Tak wielka jest pycha i jej ze wszech miar daremne urojenie"19.

Po utożsamieniu „sidła” z cytowanego przez Apostoła złorzeczenia w Ps 69, 23-24 z samym Pismem Świętym komentator rozważa zagadnienie właściwego (życiodajnego) podejścia do niego. Kluczem jest dla niego pokora: dla pysznych słowo Boże staje się narzędziem szatana, który wikła ich niechęcią do odstąpienia od własnego zdania. Konkretne odniesienie do Żydów znika na rzecz utożsamionych z nimi ludzi pysznych:

18 Tamże, s. 167.

19 Tamże, s. 168. 
„Sidłem” jest samo Pismo, mianowicie ze względu na to, że jest rozumiane i przekazywane w zwodniczy sposób, tak że pod pozorem pobożnego pouczania dusze zwiedzionych i prostych zostają podstępnie usidlone. [...] Z jednego i tego samego stołu, czyli z jednego i tego samego Pisma Świętego, jeden bierze dla siebie śmierć, a drugi życie, jeden miód, drugi truciznę. Niczego innego zatem nie należy traktować z tak wielką czcią i bez źdźbła pychy jak Słowa Bożego. Ono dumnych od razu chwyta w sidła, zamyka w pułapce i upokarza, choć czyni to w taki sposób, że tego nie dostrzegają: w rzeczy samej czyni to w urzekająco pięknym przebraniu. Nie jest to wina Słowa, lecz ludzkiej pychy, która zuchwale powstaje przeciw niemu. „Kamień obrazy” to nic innego jak to, że owi schwytani w sidła stale się obrażają. Skoro bowiem są usidleni, to przez to, co niewłaściwie rozumieją. Temu pozostają wierni i w tym znajdują upodobanie. [...] W końcu ich oczy są tak „zaćmione” (Rz 11, 10), że kiedy inni widzą, oni sami nie pozwalają się oświecić, a kiedy wszyscy inni wzrastają, oni pozostają zwiedzeni w swych umysłach ${ }^{20}$.

W dalszym ciągu dla Marcina Lutra kluczem interpretacji fragmentu Listu, w którym Paweł zastanawia się nad przyczyną i skutkami odrzucenia Ewangelii przez część Izraela, jest kontrast pychy i pokory.

Boże zarządzanie jest takie, że wyświadcza dobro tym, którzy są pokorni, mianowicie wybranym. Lecz nie stanie się to, dopóki pyszni, którzy nie pojmują tego oświecenia, nie staną się jeszcze bardziej „zaćmieni” i jeszcze bardziej zgorszeni.

Tu komentator Listu powołuje się na przykłady z Ewangelii: „dumnego starszego syna” z Łk 15 i robotników „rozwścieczonych” obdarowaniem przez gospodarza innych w przypowieści z Mt 20,1-16. Przytoczony przez Apostoła obraz grzbietu zgiętego ku ziemi (Ps 69, 23-24) również oskarża zadufanych w sobie:

Stosownie do znaczenia przenośnego znaczy to, że ci, którzy pochylają plecy, nie mogą już spoglądać w górę do Boga. Zatem nie dostrzegają już sprawiedliwości, która spogląda z nieba w dół, ale uznają tylko swoją sprawiedliwość, do której dążą i w której pokładają ufnośćé

20 Tamże, s. 169.

21 Tamże, s. 170. 
Tak więc zmaganie się autora komentarza z własnym zderzeniem się ze słowem Bożym, które może - odczytane bez pokory - wprawić w rozpacz, jego gwałtowne poszukiwanie kryterium pozwalającego w nim odczytać zbawcze miłosierdzie odwodzi jego myśl od troski Pawła o swych rodaków i jego próby wytłumaczenia ich „potknięcia”.

Zainteresowanie obu komentatorów Listu Apostoła Narodów budzi też podwójna metafora zaczynu i ciasta oraz oliwki szlachetnej i dzikich pędów. To przy tej okazji wyraźniej zauważają Żydów i Narody.

W komentarzu św. Tomasza z Akwinu uwaga autora koncentruje się wokół „naturalności” wszczepienia Żydów w pień drzewa i „nienaturalności” wszczepienia pogan. Najpierw - zgodnie z biegiem myśli Apostoła - pokazuje on, na czym polega „szlachetność” oliwki Izraela (w przeciwieństwie do bezpłodności pogan), tłumacząc „korzeń” i „tłustość” oliwki przez odniesienie do Ojców Izraela i Apostołów Chrystusa:

Otóż oliwką nazywany jest sam lud żydowski, a to ze względu na obfite owoce duchowe, jakie przynosił. „Urodzajną oliwką, piękną, przynoszącą owoce, ozdobą nazwał cię Pan” (Jr 11, 16). „Ja zaś jak oliwka, która przynosi owoce w domu Bożym” (Ps 51, 10). Otóż podobnie jak korzeniem tej oliwki są patriarchowie i prorocy, tak samo tłustością tej oliwki jest obfitość łaski Ducha Świętego, a tej - jak powiada Glosa ${ }^{22}$ - mieli apostołowie więcej niż wszyscy ${ }^{23}$.

Dalej św. Tomasz rozwija dłuższą dygresję nad sensem określenia „naturalny” w odniesieniu do działania Bożego: nic, co czyni Bóg, nie jest „nienaturalne”, bo wszelkie stworzenie „z natury” Mu podlega. Pisze, komentując na bieżąco tekst Listu:

„Albowiem jeżeli ty” - który pochodzisz z pogaństwa - „Zostałeś odcięty od naturalnej dla ciebie dziczki oliwnej” - czyli od pogaństwa, które z natury było bezpłodne, choć nie dlatego, jakoby Bóg stworzył taką naturę, ale ponieważ uległa ona zepsuciu wskutek grzechu: „Niegodziwe jest ich pochodzenie, a złość ich wrodzona” (Mdr 12, 10); „Z natury

22 Czyli według objaśnienia Jacka Salija OP - Piotra Lombarda Collectanea In Epistolam ad Romanos (PL 191, 1486), por. przypis 9 na s. 176.

23 Św. Tomasz z Akwinu, Wykład Listu do Rzymian, dz. cyt., s. 176. 
byliśmy synami gniewu” (Ef 2, 3) - i „wszczepiony zostałeś w oliwkę szlachetną” - to znaczy w wiarę Żydów - „przeciw naturze” - bo wbrew ogólnemu biegowi natury. Nie zdarza się przecież, żeby gałąź złego drzewa wszczepiano w drzewo dobre, raczej czyni się odwrotnie ${ }^{24}$.

W tym rozważaniu można zauważyć uznanie Tomasza dla „szlachetności” żydowskiej „natury”, jak również jego sposób argumentacji z Pisma Świętego - przez przywoływanie różnych innych jego fragmentów. Powołuje się on jednak również na „księgę natury”, odnosząc się do ówczesnej wiedzy przyrodniczej:

Otóż to, co czyni Bóg, nie jest przeciwne naturze, lecz jest czymś bezwzględnie naturalnym. Naturalnym nazywamy bowiem to, czego dokonuje sprawca, któremu doznający podlega z natury, choćby nawet nie było to zgodne z własną naturą doznającego. W ten sposób na przykład naturalny jest przypływ i odpływ morza, jako że dokonuje się w wyniku biegu księżyca, któremu woda podlega z natury, chociaż nie jest on naturalny ze względu na właściwości wody ${ }^{25}$.

Dla Żydów zatem czymś „naturalnym” jest tak „ciążyć” ku Bogu, jak dla wody opadać w dół. Natomiast poganie z „natury” własnej ciążyliby ku bezbożności, ale muszą ulec Bożej łasce, jak morze księżycowi - wbrew sobie. Poganie wprawdzie mogliby się upierać, że „ludy pogańskie są Bogu droższe i milsze niż Judea” i podeprzeć się zasadą, według której „ktoś zgadza się ponieść szkodę w jednej rzeczy, tylko ze względu na rzecz bardziej cenną i więcej umiłowaną”"6 czyli stracić zysk z wierności Żydów Bóg mógłby tylko z tego względu na większą w Jego oczach wartość wiary w ludach o większej wartości. Tomasz odrzuca jednak taki powód chełpienia się, wskazując, że jednych i drugich zrównuje Bóg ze względu na ich stosunek do wiary w Chrystusa, która jest kluczem do otrzymania łaski zbawienia. Apostoł mówi poganinowi:

24 Tamże, s. 178.

25 Tamże, s. 177-178.

26 „W ten sposób lekarz dopuszcza do choroby w nodze, aby uleczyć oko” (św. Tomasz z Akwinu, Wykład Listu do Rzymian, dz. cyt., s. 177). 
Bóg dopuścił odłamanie gałęzi, abyś ty mógł być wszczepiony, ale zastanów się nad powodem, dla którego gałęzie zostały odłamane: „odcięto je na skutek niewiary” - albowiem nie chcieli uwierzyć w Chrystusa. [...] „Ty zaś” - który pochodzisz z pogan - „stoisz dzięki wierze” - mianowicie jako wierzący w Chrystusa, w którym dostąpiłeś łaski²7.

Myśl Tomasza, zauważając Pawłowe przekonanie o szczególnej pedagogii Boga wobec ludu, który sobie utworzył, ciąży jednak ku abstrakcji, ku wydobyciu z konkretnej troski Apostoła Narodów ogólnych zasad analogicznych do praw natury.

Doktor Marcin Luter, odnosząc się do metafory zaczynu i szlachetnej oliwki, skupia się na zasadzie usprawiedliwienia przez łaskę i wiarę w miłosierdzie Boże, a nie we własną sprawiedliwość. Podobnie jak Tomasz zauważa on ojcowską preferencyjną miłość Boga do Izraela nie tylko do Żydów trwających przy Bogu, ale i do tych, którzy się potknęli, lecz po to, żeby mieć jeszcze jeden argument przeciw chlubiącym się uczynkami.

Przez dwojakie podobieństwo apostoł dostarcza dowodu, że należy wywyższać Bożą łaskę, a ukracać zuchwałość chlubiących się sprawiedliwością. W naturze jest to zasadą: jeśli pierwociny są dobre, to i całe plony będą dobre; i gdy korzeń jest dobry, to również drzewo, które z niego wyrasta, jest dobre. Tak jest i tutaj. Gdyby nie było pewne, że Boża łaska ma być wywyższana, całemu ludowi przypadłoby w udziale jednakie dostojeństwo ${ }^{28}$.

Nie przypada jednak teraz tym, którzy pysznią się swoją przynależnością według ciała do Izraela. Komentując Rz 11, 24, pisze Luter:

Z nasienia drzewa oliwnego nie wyrasta dobre drzewo, co pokazuje, że dzieci narodzone według ciała nie są dziećmi Bożymi i że Żydzi nie dostąpili chwały Ojców jedynie dlatego, że byli ich nasieniem. Prawdą jest raczej coś zupełnie przeciwnego. Jak dzikie drzewo oliwne staje się dobrą gałęzią, nie z natury, lecz przez sztukę wszczepienia, tak

27 Św. Tomasz z Akwinu, Wykład Listu do Rzymian, dz. cyt., s. 177.

28 M. Luter, Komentarz do Listu do Rzymian, dz. cyt., s. 172. 
też poganie stają się ludem Bożym, nie dzięki naturalnej sprawiedliwości czy prawości, lecz dzięki łasce im zaszczepionejej ${ }^{29}$.

Z drugiej strony, przy komentowaniu metafory oliwki jasno i gwałtownie przeciwstawia się on szerzeniu z tego tytułu pogardy do Żydów. Wynika to z zasady niechełpienia się własną doskonałością. W nawiązaniu do słów: „Obaczże tedy dobrotliwość i srogość Bożą” (Rz 11, 22) pisze:

Z fragmentu tego dowiadujemy się, że gdy widzimy upadek Żydów, heretyków i innych, nie powinniśmy tak bardzo skupiać uwagi na tych, co upadają, lecz raczej na dziele Bożym, które On w ich sprawie wykonuje, tak że możemy na przykładzie nieszczęścia przytrafiającego się innym uczyć się bojaźni Bożej i tego, by w żadnym wypadku zuchwale się nie chlubić. Wielu postępuje zupełnie odwrotnie, wywyższając siebie samych w zdumiewająco głupi sposób i nazywając Żydów albo psami, albo przeklętymi lub znieważając ich innymi obelgami, choć sami nie wiedzą, jakiego rodzaju ludźmi są i jakimi są w oczach Bożych. Siłą bądź wyzwiskami chcą nawracać Żydów. Niech Bóg im stanie na drodze ${ }^{30}$.

Częściowe umniejszenie, zebranie w całość i życie spośród umarłych Marcin Luter komentuje z wyraźną świadomością preferencyjnej miłości Boga do Izraela:

Jeżeli wiara przyszła do pogan jako skutek potknięcia się Żydów, o ileż więcej by jej przyszło, gdyby Żydzi mocno w niej trwali. A zatem Żydzi nie upadli jedynie, „by upaść”, lecz raczej, by mogli powstać znowu, zachęceni przykładem pogan. Bóg nie mógł ich zdobyć przez samo pouczanie. Dlatego starał się pozyskać ich przez wzbudzenie w nich zazdrości, jak kochający ojciec postępuje zwykle ze swoim synem. Jeżeli zbawienie dotarło do pogan przez upadek Żydów, ażeby ich potknięcie nie pozostało bez owoców, a zło bez dobra, jako że dla tych, którzy Boga miłują, wszystkie rzeczy współdziałają ku dobremu (Rz 8, 28), o ileż bardziej zło musi dopomagać Chrystusowi i Bogu. Co więcej, zło musi współdziałać ku dobremu w nadzwyczajnym natężeniu, jeśli kieruje tym Bóg.

29 Tamże, s. 172-173.

30 Tamże, s. 172. 
[...] W tym znaczeniu ich upadek przysłużył się zbawieniu pogan; ale nie to było jego ostatecznym celem, bo jego przeznaczeniem było nakłonić ich do współzawodnictwa o błogosławieństwa z tymi, którzy zostali podźwignięci ${ }^{31}$.

Wyprowadzenie dobra ze zła potknięcia się Żydów interesuje więc Lutra przede wszystkim dlatego, że okazuje wielkość dzieła miłosiernego Boga w zbawieniu świata. „Świat” przeciwstawia przy tym „Żydom” i wskazuje na miłość Boga do ludu pierwszego wybrania. Komentując Rz 11, 15, pisze:

Nie można tego brać za przyczynę, bo nadeszło jako skutek, gdyż za niewiarą Żydów przyszło pojednanie świata. Lecz nie musiałoby przyjść, gdyby mocno trwali w wierze, co bez wątpienia wynika z Dz 10, 44-48. Widzimy tam, że łaska Ducha Świętego została wylana na pogan, czym apostołowie, nie będący jeszcze pewni odrzucenia Żydów byli wielce zdumieni.

Dla Lutra jednak aktualne odrzucenie „Żydów” jest pewne i wskazuje na nie jako na motyw gorliwości św. Pawła w głoszeniu Ewangelii światu pogańskiemu:

Apostoł przemawiał do Żydów i został odrzucony (Dz 13, 46). Dlatego wysławiał swój urząd między poganami, ażeby pobudzić Żydów do współzawodniczenia. Co bowiem traktujemy ze wzgardą, gdy nam się to oferuje, zazwyczaj wysoko cenimy, gdy biorą to inni, gdyż ulegamy ich osądowi ${ }^{32}$.

Św. Tomasz widzi misterium zbawienia „całego Izraela” jako wejście Żydów do Kościoła u kresu czasów. Wychodzi jednak w komentarzu do Rz 11, 25-27 od kwestii „zaślepienia po części”. Pisze:

Wreszcie Apostoł przedstawia swoją tezę. Najpierw jednak w odniesieniu do upadku poszczególnych Żydów. Powiada, że ślepota ogarnęła Izrael nie powszechnie, ale w jakiejś części, jak to wykazano wyżej, w Rz 11, 1-2. „Zaślep serce tego ludu” (Iz 6, 10). Następnie

31 Tamże, s. 170-171.

32 Tamże, s. 171 
apostoł powiada, jak długo to zaślepienie będzie trwało. Powiada: „dopóki nie wejdzie - do wiary - pełnia pogan”. Chodzi nie tylko o to, żeby nawrócili się niektórzy z poszczególnych narodów, tak jak to się działo dotychczas, ale o to, żeby - bądź w całym narodzie, bądź w jego większej części - Kościół został ustanowiony we wszystkich narodach ${ }^{33}$.

\section{Następnie zastanawia się nad sensem określenia „dopóki”.}

Zauważmy jeszcze, że wyraz „dopóki” może wskazywać na przyczynę zaślepienia Żydów. Dlatego bowiem [...] dopuścił Bóg ich zaślepienie, aby weszła pełnia pogan. Wyraz ten może również wskazywać na kres: tak długo będzie trwało zaślepienie Żydów, dopóki nie wejdzie do wiary pełnia narodów ${ }^{34}$.

\section{Tak więc dla św. Tomasza nie ulega wątpliwości, że „zebranie w jedność”} Izraela dokona się przez przyjęcie chrztu i tak rozumie św. Pawła:

Następnie Apostoł udowadnia swoją wypowiedź na temat przyszłego zbawienia Żydów. [...] Zatem najpierw powiada tak: „Mówię, że cały Izrael zostanie zbawiony, tak jak to jest napisane w Iz 59, 20”35. Podkreśla trzy zawarte w proroctwie obietnice. Po pierwsze, przyjście Zbawiciela. Powiada: „Przyjdzie” - mianowicie Bóg, który dla naszego zbawienia stanie się człowiekiem - ,z Syjonu” czyli z ludu żydowskiego, którego Syjon jest tutaj symbolem. [...] Albo też słowo, że przyjdzie On z Syjonu, nie dotyczy tego, że tam się On narodził, ale że stamtąd jego nauka rozeszła się na cały świat, jako że w wieczerniku na Syjonie apostołowie otrzymali Ducha Świętego. Po wtóre w tekście podkreśla się, że zbawienie zostało ofiarowane Żydom przez Chrystusa. Powiedziano: „który wyrwie i odwróci bezbożność od Jakuba”. Wyrwanie można tu odnieść do wybawienia od kary. „Wyrwie moją duszę od śmierci” (Ps 114, 8). Słowa zaś: „odwróci bezbożność od Jakuba” można odnieść do wybawienia od winy. „Odwróci Pan niewolę swojego ludu”. Albo i jedno i drugie do wyrwania od winy - wtedy „wyrwie” odnosi się do tych nielicznych Żydów, którzy teraz nawracają się z trudnością, jakby do tego przymuszeni. [...] Wtedy słowa „odwróci bezbożność od Jakuba” zapowiadają łatwość nawrócenia Żydów przy końcu świata. Po trzecie wskazuje na sposób, w jaki zostanie dokonane zbawienie.

33 Św. Tomasz z Akwinu, Wykład Listu do Rzymian, dz. cyt., s. 178-179.

34 Tamże, s. 179.

35 Warto zauważyć, że Tomasz ma świadomość, iż Paweł cytuje Izajasza według Septuaginty. 
Czytamy: „I to będzie moje z nimi przymierze” - nowe mianowicie - „gdy zgładzę ich grzechy”. Stare bowiem Przymierze nie gładziło grzechów ${ }^{36}$.

Wrażliwy na paradoksalność Objawienia Marcin Luter z wierszy Rz 11, 26-27 wydobywa przede wszystkim pouczenie o zasadności szacunku dla całego ludu Izraela, który opiera się na obecności wśród nich wybranych ${ }^{37}$.

By właściwie zrozumieć apostoła, musimy mieć na uwadze, że jego oświadczenie obejmuje całe zgromadzenie narodu żydowskiego. Nawet jeśli niektórzy spośród nich są odrzuceni, pomimo to cały lud ma być w poważaniu z powodu wybrania. [...] W tym sensie lud żydowski jest „świętym zgromadzeniem”, a to z powodu wybrania, jednak ze względu na odrzuconych są Żydzi „odciętą gałęzią”. Tym sposobem są Żydzi zarówno „pełnością”, jak i „opustoszeniem”. Apostoł nazywa ich „zgromadzeniem”, aby pokazać, że nie mówi o pojedynczych osobach, ale o całym ludzie, w którym niewielu może być świętych ${ }^{38}$.

Widzimy zatem, że według obu omawianych komentatorów przyszłe przymierze z Izraelem, o którym mówi św. Paweł, dokona się przez zgładzenie grzechów i kojarzy się jednoznacznie z przyjęciem ich do Kościoła przez chrzest. Zauważają też, że w Pawłowym proroctwie chodzi o jakieś zbiorowe nawrócenie, które można by uznać za akt dokonany przez lud w całości. Św. Tomasz rozważa różne wersje scenariusza owego nawrócenia, natomiast Marcin Luter w ogóle się nad tym nie zatrzymuje, wyciągając jedynie wniosek praktyczny o konieczności poszanowania dla ludu Izraela ze względu na obecność w nim nawet nielicznych (znanych Bogu) świętych.

W następnych kilku wierszach Listu zawierają się między innymi słowa uznane przez ojców Soboru Watykańskiego II za kluczowe dla

36 Św. Tomasz z Akwinu, Wykład Listu do Rzymian, dz. cyt., s. 179.

37 Luter rozciąga tę zasadę poszanowania na wszelkie społeczności: „Należy zatem szanować każdą społeczność ze względu na dobrych pośród nich, nawet kiedy są w mniejszości wobec niegodziwych” (M. Luter, Komentarz do Listu do Rzymian, dz. cyt., s. 174).

38 Tamże. 
uzasadnienia reorientacji w stosunkach Kościoła z Żydami ${ }^{39}$. Zobaczmy, co widzą w nich omawiani autorzy.

Św. Tomasz rozważa dokładny sens określenia Żydów „nieprzyjaciółmi” i „najdroższymi” ${ }^{40}$. Komentując Pawłowe przedstawienie powszechnej potrzeby miłosierdzia Bożego, zwraca uwagę nie tyle na przeplatanie się losów Izraela i Narodów w dziejach, co na konieczność łaski do zbawienia ${ }^{41}$. Z kolei jego uwagę przykuwa rodzaj zasady powszechnej woli zbawczej Boga: rozciąga się ona jego zdaniem na poszczególne kategorie stworzeń, a nie na jednostki. W ten sposób próbuje przeciwstawić się „konieczności” powrotu wszystkich do Boga („orygenizm”). W końcu wzywa do uniżenia i pokory: zbawienia nie można przypisywać sobie, lecz tylko Bogu ${ }^{42}$. Temat „wybrania” Izraela ze względu na ojców wiary wprowadza w komentarzu św. Tomasza dyskusję o stosunku wolnej woli i „przedwiedzy” Boga. Tym samym komentator odchodzi od tematu misterium zbawienia Izraela ${ }^{43}$. Dalej włącza dygresję na temat otrzymywania łaski chrztu „bez pokuty” (sine poenitentia) - zna więc i tę interpretację łacińskiego przekładu wersetu ${ }^{4}$.

Komentarz Marcina Lutra do Rz 11, 29 jest krótki. Stwierdzenie św. Pawła: „według Ewangelii nieprzyjaciółmi są dla was” znów brzmi dla niego paradoksalnie, wskazując na związek z tajemnicą Boga. Żydzi jawią mu się jako „nieprzyjaciele” zasługujący na nienawiść ze strony wiernych Bogu i „umiłowani” jednocześnie przez Boga.

Słowo „nieprzyjaciele” należy tu rozumieć w znaczeniu biernym; to znaczy, że zasługują oni na nienawiść. Bóg nienawidzi ich, znienawidzeni są zatem przez apostołów i wszystkich, którzy są z Boga. Zostało to pokazane poprzez przeciwstawne słowo „umiłowani”. Są nienawidzeni i jednocześnie są umiłowani. Są nienawidzeni „według Ewangelii

39 Por. Sobór Watykański II, konst. Lumen gentium, 16; Sobór Watykański II, dekl. Nostra etate, 4 - z powołaniem się obu na $\mathrm{Rz} 11,28-29$.

40 Św. Tomasz z Akwinu, Wykład Listu do Rzymian, dz. cyt., s. 180-181.

41 Tamże, s. 181-182.

42 Tamże, s. 182.

43 Tamże, s. 180-181.

44 Tamże, s. 181. 
[...] dla was”. To znaczy: Jak wy jesteście umiłowani, przyjmując Ewangelię, tak oni są nienawidzeni, odrzucając Ewangelię. Mimo to zgromadzenie jest umiłowane „według wybrania [...] dla ojców”. Oznacza to, że niektórzy z nich z powodu wybrania aż do ostatniej godziny będą zachowani. Są umiłowani ze względu na Ojców, ponieważ jak i oni są przyjaciółmi ${ }^{45}$.

Komentator zdaje się być przekonany o słuszności znienawidzenia Żydów w społeczności chrześcijańskiej, a szacunek dla nich stara się budować na przekonaniu o istnieniu w społeczności żydowskiej nielicznych wybranych przez łaskę „przyjaciół”. Pawłowe stwierdzenie, że „darów swoich i wezwania Bóg nie żałuje”, wywołuje jego zachwyt, który jednak nie dotyczy zbawienia Izraela, lecz wyczytanej w tekście odpowiedzi na jego własny niepokój o zbawienie:

Cóż za cudowne zapewnienie. Bożego zamysłu nie odmienia żadna ludzka zasługa lub jej brak. Bóg nigdy nie żałuje swoich darów i powołania, które obiecał, ze względu na to, że wybrani są niegodni, a wy we własnych oczach wydajecie się godnymi. On nie odmienia swojego zamysłu. A zatem wybrani z pewnością będą nawróceni i przyjdą do prawdziwej wiary ${ }^{46}$.

Przechodząc wreszcie do Pawłowego hymnu uwielbienia kończącego rozdział, Tomasz z Akwinu dostrzega jego związek z poprzednim roztrząsaniem tajemnicy zbawienia Izraela i Narodów, ale szybko przechodzi do rozważań nad mądrością Bożą, które abstrahują od tego związku ${ }^{47}$. Do końca jego wykładu na temat 11 rozdziału nie znajdziemy już odniesienia do zbawienia Izraela, co dobrze pokazuje główne zainteresowania komentatora samym misterium Boga ${ }^{48}$. Końcowy hymn dla Lutra jest uwielbieniem Boga za niepoznawalność Jego zrządzeń (wyborów) siłami naturalnego rozumu (przeciw Arystotelesowi). Rozróżnia (za Augustynem) mądrość (w której mamy ciemny udział przez wiarę)

45 M. Luter, Komentarz do Listu do Rzymian, dz. cyt., s. 174.

46 Tamże, s. 174-175.

47 Św. Tomasz z Akwinu, Wykład Listu do Rzymian, dz. cyt., s. 183.

48 Tamże, s. 183-185. 
od poznania stworzeń dokonującego się „poza Bogiem” - bez relacji do Niego ${ }^{49}$.

Wydaje się, że prześledzenie tematu Izraela w tych dwóch komentarzach, choć nie zastąpi gruntownego studium historii problemu w wiekach średnich, wnosi jednak pewne światło w zrozumienie losów odsunięcia na margines myśli chrześcijańskiej zagadnienia misterium Izraela, które nurtowało św. Pawła i było istotne w jego przekonaniu dla wszystkich uczniów Chrystusa.

\section{Abstrakt}

\section{Izrael i jego "misterium" w komentarzach do Listu do Rzymian św. Tomasza z Akwinu i Marcina Lutra}

Od II wieku kształtuje się takie rozumienie roli Starego Testamentu dla życia Kościoła i jego teologii, w którym Żydzi nieprzyjmujący Jezusa nie mają już pozytywnego znaczenia dla dalszych dziejów zbawienia, Kościół przejął bowiem wszystkie prerogatywy dawnego ludu Izraela. Summy teologiczne systematyzujące myśl teologiczną w okresie średniowiecza nie zawierają całościowej myśli o Kościele. Tym samym nie włączają w system teologiczny nauki o miejscu Izraela i Żydów w dziejach zbawienia po Chrystusie. W teologii problem tożsamości Kościoła pojawia się dopiero u schyłku tego okresu w związku z kryzysem, który wtedy przeżywa. Dwa w pełni opracowane komentarze do Listu do Rzymian autorów o kolosalnym znaczeniu dla dziejów myśli europejskiej - Tomasza z Akwinu (z roku 1273) i Marcina Lutra (z roku 1518) - dają wgląd w rozumienie Izraela i jego „misterium”. Analizujemy ich ujęcie tematu przy tłumaczeniu 11 rozdziału Listu. W efekcie, mimo różnicy w podejściu każdego z nich, można zauważyć, jak zagadnienia ciążące w tradycji nad interpretacją tej księgi owocują odsunięciem na margines myśli chrześcijańskiej zagadnienia misterium Izraela, które nurtowało św. Pawła i było istotne w jego przekonaniu dla wszystkich uczniów Chrystusa.

Słowa kluczowe: Tomasz z Akwinu, Marcin Luter, List do Rzymian, Kościół, Izrael, Żydzi

49 M. Luter, Komentarz do Listu do Rzymian, dz. cyt., s. 175. 


\section{Abstract}

\section{Israel and Its "Mystery" in St. Thomas Aquinas' and Martin Luther's Commentaries to the Epistle to the Romans}

Beginning with the second century AD, there has developed an understanding of the role of the Old Testament in the life of the Church and its theology in which Jews who reject Jesus no longer have a positive role in subsequent salvation history as the Church has taken over all the prerogatives of ancient Israel. In the Middle Ages, summas of systematic theology did not contain comprehensive thinking about the Church. At the same time, they do not include teachings about the role of Israel and the Jews in salvation history after Christ in their theological system. In theology, the problem of the identity of the Church appeared only at the end of the Middle Ages due to its crisis. Two complete commentaries on the Epistle to the Romans by St. Thomas Aquinas (from 1273) and Martin Luther (1518), authors who played a colossal role in the history of European thought, give us insight into the understanding of Israel and its "mystery." We analyze how this topic is conceptualized in the eleventh chapter of the epistle. Despite the difference in each author's approach, we can see how this topic weighs on tradition in the interpretation of this book, relegated the topic of the mystery of Israel, which rankled St. Paul and was in his view important for all of Christ's disciples, to the margins of Christian thought. Keywords: Thomas Aquinas, Martin Luther, Epistle to the Romans, Church, Israel, Jews

\section{References}

Augustyn. (1952). Pisma katechetyczne (W. Budzik, Trans.). Pax.

Luther, M. (2009). Komentarz do Listu do Rzymian. Tymbes.

Pesch, O. H. (2008). Zrozumieć Lutra (A. Marniok \& K. Kowalik, Trans.). W drodze.

Todd, J. M. (1998). Marcin Luter (T. Szafrański, Trans.). Vocatio.

Tomasz z Akwinu. (1987). Wykład Listu do Rzymian. Super epistolam S. Pauli Apostoli ad

Romanos (J. Salij, Trans.). W drodze.

Vatican Council II. (1964). Lumen gentium.

Vatican Council II. (1965). Nostra aetate.

Weisheipl, J. A. (1985). Tomasz z Akwinu. Życie, myśl i dzieło (C. Wesołowski, Trans.).

W drodze. 